\title{
SOME 1965 BIRD RECORDS FOR THE SASKATOON DISTRICT
}

\section{by J. Bernard Gollop, Jaines A. Slimmon and Robert V. Folker, Saskatoon}

The following is a list of some of the more interesting bird observations made during 1965 in the Saskatoon district. The area included is a square, 60 miles on a side, centered on the city -Townships 31 through 40, Ranges 1 through 10 , west of the Third Meridian. Observations were made by the authors except where otherwise noted.

Several species were more common this year than in previous years; Yellow-bellied Sapsuckers (Sphyrapicus varius), Red-breasted Nuthatches (Sitta canadensis), thrushes, warblers and sparrows were particularly common in fall migration. Warblers, mainly Myrtle (Dendroica coronata) and Palm (D. palmarum), were noted in flocks of 20 to 200 along roads from September 11 to 19. Cape May Warblers (D. tigrina) were more common than usual in fall migration and were noted until September 25 (J. F. Roy). Lark Buntings (Calamospiza melanocorys) were much more common than in previous years from May 23 to August 10; 56 were recorded in 16 miles around Goose Lake on July 19.

On July 11, 5,550 Franklin's Gulls (Larus pipixcan) flew into Strehlow Pond to roost. Some of these birds had flown 13 miles from feeding fields near Saskatoon. More than 60 fallplumaged Bobolinks (Dolichonyx oryzivorus) at Proctor Lake on August 14 constituted another large flock for this area. What were large flocks of two species for this area in winter were found on December 27 in a stubble field partly covered with manure: at least 57 magpies (Pica pica) and 53 Starlings (Sturnus vulgaris). An apparently healthy meadowlark (Sturnella neglecta) on December 19 at Hanley was the first winter record of this species.

Three species were particularly rare this year. Two Rough-legged Hawks (Buteo lagopus) on October 9 and one on October 23 were the only fall records. Single Short-eared Owls (Asio flammeus) on April 24, May 8 (M. A. Gollop), October 2, 18 and 24 are the only records; the species was common in 1964. Snowy Owls (Nyctea scandiaca) were fairly common from October 24 through November but scarce in December. The first record of Bohemian Waxwings (Bombycilla garrulus) for the current season was December 23 (60 birds); in 1964 it was October 25 (12+ birds).

Several species were recorded breed.. ing for the first time in this area. A nest of the Virginia Rail (Rallus limicola) with $10 \mathrm{eggs}, 9$ to 10 days incubated, was found among dead cattails in Hudson's Bay Marsh on June 22. Both adults were seen and heard. The nest of a Yellow-bellied Sapsucker (Sphyrapicus varius) was located eight feet from the ground in an aspen at Beaver Creek with nearly full-grown young on July 5 (J. Black and JAS). Purple Martins (Progne subis) were noted in the vicinity of the potash plant at Patience Lake from May 24 to Augurst 31. On June 15 a male was picking leaves from the tops of aspens and flying to the buildings with them; on the same date at least six martins, male and female, were observed disappearing under the eaves of the most northerly silo at the plant. A nest of Le Conte's Sparrow (Passerherbulus caudacutus) with one recently hatched young and a cowbird's (Molothrus ater) egg was found 10 miles southeast of Saskatoon on July 24. The young was photographed on July 26 and the nest was empty on July 31. In addition, Lark Sparrows (Chondestes grammacus) were found breeding; one nest with one egg and another with four young were found near Clark's Crosising on June 20 ( $\mathrm{J}$. D. Hogg) .

An extensive wooded area in the PFRA Community Pasture, seven miles northeast of Asquith, produced 
some previously unrecorded summer specie's for this area. Swainson's Thrushes (Hylocichla ustulata) were common from June 13 to July 17 (date last visited). At least two Ovenbirds (Seiurus aurocapillus) were heard on June 13. A Slate-colored Junco (Junco hyemalis), acting as though it had a nest, was seen on June 25 (M. A. Gollop), and an Orangecrowned Warbler (Vermivora celata) was studied as it sang for about 20 minutes in an opening on July 10.

There are three records of particularly late nesting. A brood of five flightless young Mallards (Anas platyrhynchos) wars seen at Radisson Lake on October 7. The first egg was probably laid about July 7. A Mourning Dove (Zenaidura macroura) nest had two eggs on August 17 at Beaver Creek; there was one egg left on August 19 and a 4- or 5-day-old young was banded by C. S. Houston on August 25. The successful egg was probably laid about August 8. A nest of Cedar Waxwings (Bombycilla cedrorum) 20 feet up in a Manitoba maple with three young almost ready to fly on September 8 was reported by Mrs. Gordon Brampton, Avenue J. The estimated date of laying was August 11.

The CFQC-TV Tower apparently killed less than half as many birds on southward migration this year as last. The 142 birds killed on five successive nights from August 30-31 to September 3-4 made up more than $90 \%$ of the 1965 kill (M. A. Gollop).

Ten species were recorded for the first time in recent years, bringing the total for the district to 258. An adult female Ross' Goose (Chen rossii) was shot by hunters on September 25 at Rice Lake. Five Buffbreasted Sandpipers (Tryngites subruficollis) were studied in a pasture near Radisson Lake on May 23. Two Great Crested Flycatchers (Myiarchus crinitus) spent several hours at 2202 York Avenue on September 2 (M. A. Gollop). A Boreal Chickadee (Parus hudsonicus) appeared at a feeding tray at 863 University Drive several times between October 17 and November 24 (C. S. Houston). A Short-billed Marsh Wren (Cistothorus platensis) was seen on May 15, 10 miles northwest of Dundurn (J. D. Hogg and J. Shadick). A Goldencrowned Kinglet (Regulus satrapa) was observed on September 19 at the Saskatoon Airport. A male Scarlet Tanager (Piranga olivacea) in full breeding plumage was studied at a feeding tray at 834 Temperance Street on August 19 (Mr. and Mrs. T. C. Vanterpool). A male Blackheaded Grorbeak (Pheucticus melanocephalus) was seen on June 6 by several people on a Saskatoon Natural History Society field trip three miles southwest of Saskatoon. One Grasshopper Sparrow (Ammodramus savannarum) was seen but was identified only by call seven miles north of Asquith on June 19 and 25; at least two were heard on July 10. Five Smith's Longspurs (Calcarius pictus) were seen on May 15, five miles northeast of Sutherland (C. S. Houston).

Among the specie's not recorded every year but seen in 1965 were the following (single birds unless otherwise stated): Common Loon (Gavia immer) on April 24 south of Saskatoon and on June 6 in Blackstrap Coulee; Double-crested Cormorant (Phalacrocorax auritus) near Borden Bridge on May 23; Wood Duck (Aix sponsa) on May 17 south of Delisle; Turkey Vulture (Cathartes aura) on April 16 west of Asquith and August 15 west of Langham; Broad-winged Hawk (Buteo platypterus) banded on September 7 at Beaver Creek (K. Thue and C. S. Houston); Osprey (Pandion haliaetus) at Beaver Creek on September 30; Prairie Falcon (Falco mexicanus) on May 5 at Goose Lake; twelve Knots (Calidris canutus) on Porter Lake on May 20; Hudsonian Godwit (Limosa haemastica) on May 4 and 5, a flock of 20 on May 5 and three on May 8; Parasitic Jaeger (Stercorarius parasiticus) on August 20 and 21 and an unidentified jaeger on September 3, all near Patience Lake; Hawk Owl (Surnia ulula) in Saskatoon on December 22, 23 and 24 (seen by Joe and Marvin 
Smith, later identified by R. Folker and C. S. Houston); Yellow bellied Flycatcher (Empidonax flaviventris) banded at Beaver Creek on August 29 and September 5 (C. S. Houston), killed at TV tower on September 3; Traill's Flycatcher (Empidonax traillii) banded on September 12 and 19 at Beaver Creek (C. S. Houston) ; Raven (Corvus corax) on September 26 (Saskatoon, P. Andres), October 3 (Highway 60), October 17 (Saskatoon, J. F. Roy) and November 7 (Goose Lake); a flock of six Eastern Bluebirds (Sialia sialis) was studied on October 3 ten miles east of Donovan; Philadelphia Vireo (Vireo philadelphicus)_-TV tower kills on August 31 (G. Fox) and September 4, banded at Beaver Creek on September 12 (C. S. Houston); Blackburnian Warbler (Dendroica fusca) on May 23 near Borden Bridge (M. A. Gollop) ; Canada Warbler (Wilsonia canadensis) banded on August 20 and September 1 in Saskatoon (C. S. Houston); an adult male Western Tanager (Piranga ludoviciana) found dead beneath a window on Elliott Street on June 8 (W. J. Maher).

\title{
GREATER PRAIRIE CHICKEN IN SOUTHERN ALBERTA
}

\author{
by Bryan R. Shantz, Calgary
}

The last sight records of Greater Prairie Chicken, Tympanuchus cupido pinnatus (Brewster), reported in Alberta were in 1939 and 1940 (A. L. Rand, 1948. Birds of Southern Alberta. Nat. Mus. Canada Bull. 111; G. J. Mitchell, 1959. Alberta's Upland Game Bird Resources Queen's Printer, Edmonton). The last specimen record for the province was in 1929.

On September 14, 1965 eight Greater Prairie Chicken were seen about eight miles west of Coutts, Alberta, southeast of Lethbridge. The birds were seen about two miles north of the International Boundary. They were observed by myself and Mr. R. J. Bunnage of Glenwood, Alberta; while we were doing a range survey for the Alberta Department of Lands and Forests on the grazing lease of the Milk River Cooperative Grazing Association. The area is open rolling prairie, dominated by Idaho fescue; however, cultivated land occurs only two miles to the south, in Montana. The elevation of the site is 4,200 feet.
The birds flushed from a fence line at the approach of our truck. They were at first thought to be Sharptailed Grouse, but closer observation showed that they were not. The two distinguishing characteristics noted at the time were the heavily barred breast and the squarish tail. These are in contrast to the lightly spotted breast and the pointed tail of the Sharp-tailed Grouse. The birds flew only 200 feet, where they landed as a group and stood watching us. The birds were clearly observed with the aid of seven power binoculars for five or ten minutes and were still there when we drove away.

In view of the 25-year gap in the sight records for Alberta, it is unlikely that this flock is a remnant of the former resident population. Although it is possible that Greater Prairie Chicken may still breed in Saskatchewan (Blue Jay, 21:14, $1963)$, the species has also been recorded there only infrequently during the last 25 years (Blue Jay, 19:76$77,1961)$. 